\title{
Types of trematodes infecting freshwater snails found in irrigation canals in the East Nile locality, Khartoum, Sudan
}

\author{
Nidal A. I. Mohammed ${ }^{1 *}$, Henry Madsen² and Abdel Aziz A. R. M. Ahmed ${ }^{3}$
}

\begin{abstract}
Background: The planorbid freshwater snails of the two genera, Biomphalaria and Bulinus -have been vigorously studied due to the role they play as intermediate hosts of schistosomiasis. In Sudan specifically, most studies have focused on the chemical and ecological control of the two genera, but few studies have looked at their biological control. This study explored the coexistence of other species of freshwater snails and the two genera along with their trematode infections in relation to a number of environmental factors in the East Nile locality, Khartoum state, Sudan.

Methods: Freshwater snails from irrigation canals (abueshreens) were sampled monthly from January 2004 to December 2005. The snails were examined for trematode infections by cercarial emergence immediately after collection and then weekly for an additional four weeks to allow for the maturation of prepatent infections. Vegetation cover in the study sites as well as the physicochemical characteristics of the water, including temperature, were also recorded.

Results: A total of 10,493 snails, representing seven species, were collected. The most abundant species was Biomphalaria pfeifferi, representing $48.6 \%$ of the sample. Overall, $14.1 \%$ of the snails were found to be shedding some type of cercariae. Five species were found to have infections; among these the Bulinus truncatus species was found to be the most heavily infected, with an overall prevalence of $46.2 \%$. Double infections were recorded in only two B. truncatus snails and one Cleopatra bulimoides snail. Twenty different morphotypes of cercariae were recorded, seven of which appeared not to conform to previously described cercariae from Africa.

Xiphidiocercariae type 1 was the most common type of cercariae recovered, accounting for $44.3 \%$ of all infections. The density of snails tended to be lower during the summer months than the winter months, except for M. tuberculata snails, which were not affected by seasonal changes.

Conclusion: The findings of this study indicate that besides schistosomes, other larval trematodes are found, and some use the same intermediate hosts as the schistosomes. Further studies should be conducted to determine whether some of these trematodes could be manipulated for the biological control of schistosomiasis.
\end{abstract}

Keywords: Freshwater snails, Trematode cercariae, Biomphalaria, Bulinus, East Nile locality, Khartoum, Sudan

\footnotetext{
* Correspondence: niahmedmohamed@gmail.com

'Department of Zoology, Khartoum College of Medical Sciences, Khartoum,

Sudan

Full list of author information is available at the end of the article
} 


\section{Multilingual abstracts}

Please see Additional file 1 for translations of the abstract into the six official working languages of the United Nations.

\section{Background}

Freshwater snails receive considerable attention as they are intermediate hosts of several trematodes that cause diseases in humans and domestic animals. In Sudan, these are most notably schistosomiasis and fascioliasis. Whereas many studies have been conducted on intermediate host snails, most of these have focused on the specific intermediate host species infected with particular trematode. However, relatively few studies have dealt with the total snail and trematode fauna even though it has been suggested that other snail and trematode species may significantly affect transmission patterns of the aforementioned diseases $[1,2]$. In Sudan specifically, research has been done on the epidemiology and distribution of Schistosoma mansoni [3-9], S. haematobium [9-13], S. bovis [14, 15] and Fasciola gigantica [16, 17]. Likewise, some attention has been given to the control of their snail intermediate hosts [18-23], but no studies have been undertaken on snail abundance and host relationships of other trematode species, which are either not of medical and/or veterinary importance.

Therefore, the present longitudinal study followed seasonal density fluctuations in populations of freshwater snails and determined the prevalence of associated trematode infections in relation to various environmental $\mathrm{f}$ actors, in the East Nile locality of Khartoum state, Sudan.

\section{Methods}

Study area

The study area chosen is situated in the East Nile locality, an area of about $8000 \mathrm{~km}^{2}$ located in the northeastern part of Khartoum state, Sudan (see Fig. 1). Even though Khartoum is the smallest state in the country by area $\left(22,142 \mathrm{~km}^{2}\right)$, it is the most populous $(5,274,321$ in 2008 census). The state is geographically divided into

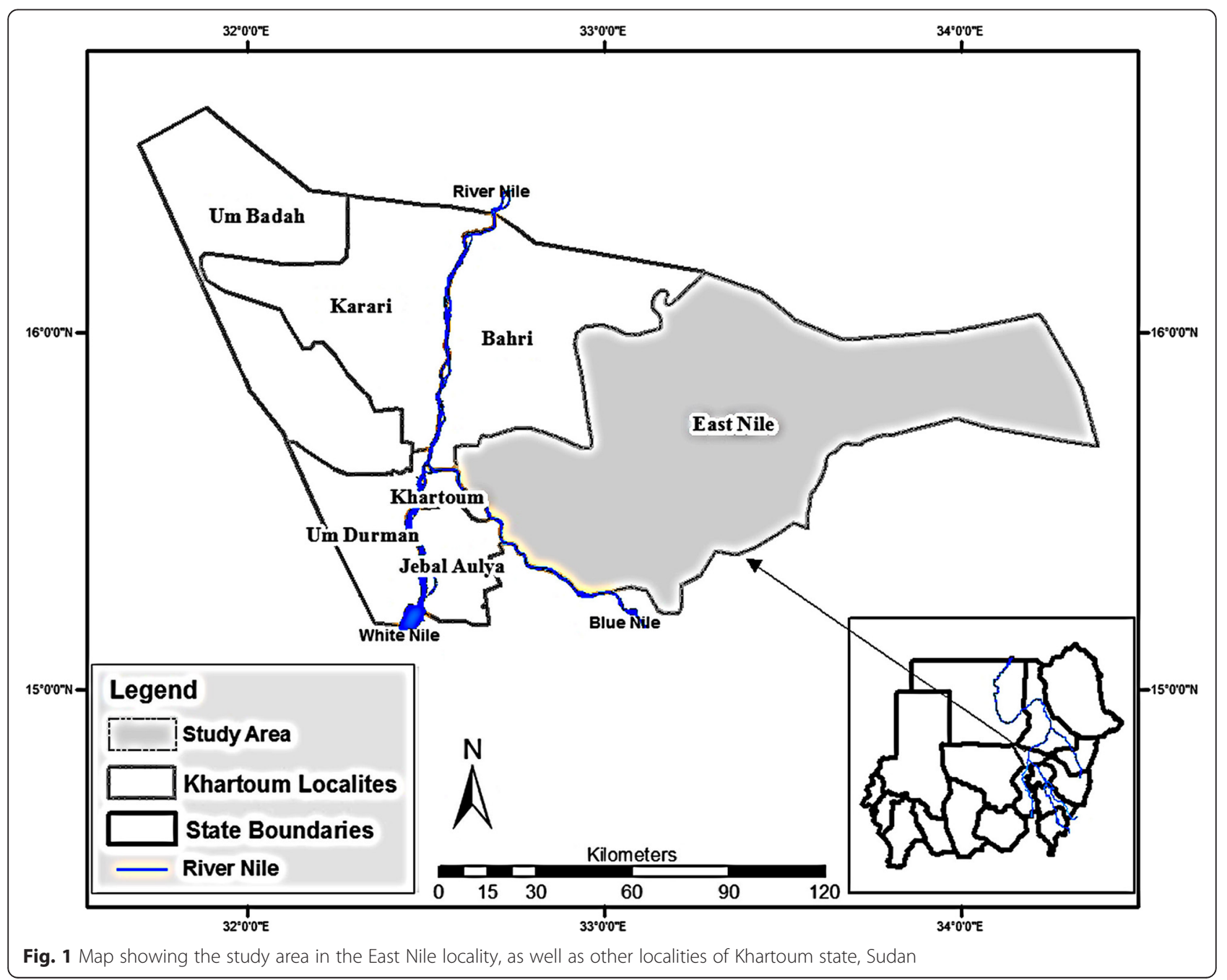


blocks (or clusters), which are further subdivided into localities. There are a total of three blocks and seven localities. Khartoum has a semi-arid climate, where the rainfall is usually $150-250 \mathrm{~mm}$ per year. The mean monthly temperature varies from $25{ }^{\circ} \mathrm{C}$ in December to $45{ }^{\circ} \mathrm{C}$ in May. The River Nile flood season coincides with the rainy season, peaking in August. Due to low rainfall and the short rainy season, agriculture is mainly of the irrigated type. Agricultural schemes are distributed along the banks of the River Nile and its tributaries; $50 \%$ of the cultivated areas are in the East Nile locality.

There are two seasons in Sudan: summer (May to September) and winter (October to April). Rain falls during the summer season from June to September, which is followed by a long dry season, extending from October to May [24].

\section{Study design and sampling techniques}

Snails and trematodes were collected monthly from January 2004 to December 2005 from canals of an irrigation system of the Blue Nile River, in the East Nile locality, Khartoum. Sampling of the snails was carried out using a scoop made of an iron frame supporting a wire mesh. Environmental and physical factors assumed to affect the presence of snails were recorded i.e. macrophyte cover and algal mass were scored visually and recorded as percentages of the area covered within the sampling sites. Temperature was measured using a mercury thermometer graduated from $0^{\circ}$ to $50^{\circ}$. Water depth was measured using a hard wooden ruler. Current velocity was measured by timing a floating object over a two -meter stretch. Shedding of trematode cercariae was conducted by traditional techniques (snails were exposed to artificial light).

\section{Selection of habitats sampled}

The agricultural flat clay land that was included in the study is about $1600 \mathrm{~km}^{2}$, with around four major agricultural projects. The study was carried out in irrigation canals (abueshreens) of two important agricultural schemes: the southern part of the Al Seilate scheme and the Arabian Company (both irrigate from the Blue Nile). The main cultivated crops are different types of vegetables and fruits, as well as animal fodder. Water-contact activities of farmers and villagers lead to them being exposed to infection with snail-transmitted diseases, especially schistosomiasis, which is considered a major health problem in this area $[9,25,26]$.

Three sampling sites, each 200-meter stretches of different irrigation canals (abueshreens) characterized by muddy substrata were selected for snail sampling. Site selection was based on: (1) the site's close proximity to dwellings; (2) preliminary field observations proving the site supports snails, has slow water current, and the presence of aquatic vegetation; and (3) if there is easy access to water for villagers and livestock. Minor canals were not included because they have high water current that do not support snails habitats, and they are not used by villagers because the edges of their banks have dense vegetation making access difficult. Lower order canals such as abusittas and gadwalls only intermittently contain water for short periods of time.

\section{Sampling and identification of snails}

Monthly collection of snails was conducted from January 2004 to December 2005. Sampling was carried out using a scoop made from a wire mesh measuring $1.5 \mathrm{~mm}$, supported on an iron frame $(40 \times 30 \mathrm{~cm})$, and mounted on a 1.5 meter long iron handle [23]. One of the authors (NAIM) carried out the sampling of snails to ensure for a standardized sampling effort. Sampling was usually performed between 8:30 am and 10:30 am, for $15 \mathrm{~min}$ at a time. Alive snails were brought to the laboratory, where their species were identified, according to their morphological features [27].

\section{Shedding and harvesting of cercariae}

Snails were placed individually in $5 \mathrm{ml}$ glass bottles filled to half their capacity with dechlorinated tap water and exposed to artificial light for about two hours to induce shedding of cercariae [28]. The water in each bottle was then examined under a dissecting microscope for the presence of cercariae. Snails that did not shed cercariae on the first exposure were kept in glass aquaria in the laboratory and rechecked for cercarial shedding, as described above, weekly for four weeks after collection. During this period, snails were fed lettuce and mortality among the snails was low.

\section{Identification of cercariae}

Cercariae released by the snails were isolated, mounted on slides and stained with hematoxylin [28]. Morphologically cercariae types were identified based on gross characteristics, swimming behavior, resting position, and further cercarial development $[28,29]$. Cercariae belonging to the genus Schistosoma (S. haematobium and avian schistosomes) were identified by their morphological features. $S$. mansoni cercariae were identified to species level based on morphology of adult worm and egg morphology recovered from mice infected experimentally with the cercariae [25].

\section{Environmental and physical characteristics}

To explain variations in population densities of the freshwater snails, a number of environmental parameters were recorded during the study. Macrophyte cover and algal mass were scored visually and recorded as percentages of the area covered in the sampling sites. Temperature was measured using a mercury thermometer graduated from $0^{\circ}$ to $50^{\circ}$ centigrade graduation. Water depth was measured 
using a hard wooden ruler. Current velocity was measured by timing a floating object over a two - meter stretch. Water turbidity was visually graded into two categories, i.e. clear and turbid.

\section{Data analysis}

Snail counts and prevalence of infections between seasons and years, based on simple descriptive statistics, were compared. To test associations between ecological factors (some of which were recoded; see Results) and densities of the most abundant snail species and their most prevalent infections, negative binomial regression [30] and logistic regression analysis [31] were conducted, respectively, adjusting for site. Using the same procedures, snail densities and prevalence rates of infections were compared between seasons and years, adjusting for site. $P$-values less than 0.05 were considered statistically significant.

\section{Results}

A total of 10,493 freshwater snails, belonging to seven species, were collected from the study area. The most abundant species was B. pfeifferi, constituting $48.6 \%$ of the entire sample (see Table 1). Snail counts differed among these sites and also between years. For B. pfeifferi snails, the monthly arithmetic mean density in 2004 was 119.3 (see number of snails per standard search) and in 2005 it was 33.7; this difference was significant (see Table 2). The density of $B$. truncatus snails was comparable between the two years, i.e. 20.5 and 22.8 snails/standard search in 2004 and 2005 , respectively. The density of $M$. tuberculata snails was 38.8 snails/standard search in 2004 and 28.4 in 2005. The density of $B$. pfeifferi snails tended to be lower during the summer months than in the winter months, i.e. 50.9 and 93.5 snails/standard search, respectively. The same was observed for B. truncatus snails (10.7 and 27.6, snails/standard search, respectively). For $M$. tuberculata snail, density was high during the summer, i.e. 43.6 and 28.5 during summer and winter, respectively. More detailed variations in the seasonal density of selected snail species are shown in Fig. 2.
A total of 20 different types of cercariae were shed by five snail species (see Tables 3, 4, and Fig. 3); no infections were recorded in the $L$. natalensis and $P$. acuta snails. Xiphidiocercariae types 1 and 2 and another seven types (types 1, 2, 3, 4, 5, 6, and 7) of cercariae have not been previously described in Africa.

Overall, regardless of species, 1484 snails were found to be infected (see Tables 3 and 4) with trematodes. The snail species with the highest prevalence of infection was $B$. truncatus (46.2\%). Double infections were recorded in only two B. truncatus snails and one $C$. bulimoides snail. The two Bulinus snails were found to be simultaneously shedding S. haematobium and xiphidiocercariae, whereas the $C$. bulimoides snail was found to be shedding xiphidiocercariae and longifurcate-pharyngeate monostome cercariae Vivax (LPM) cercariae at the same time.

The most common type of cercariae recovered from the study area was xiphidiocercariae type 1 from $B$. truncatus snails, which accounted for $44.3 \%$ of all infections (see Tables 3 and 4 and Fig. 2). This was followed by parapleurolophocercous (29.4 \% of all infections) and LPM (4.2\% of all infections). Schistosoma mansoni cercariae represented $1.6 \%$ of all infections recorded, while $S$. haematobium (or related species) was recovered from only two B. truncatus snails $(0.1 \%)$. The avian schistosome cercariae revealed a prevalence of $1.8 \%$. Ornatae and armatae xiphidiocercariae contributed to $11.9 \%$ and $3.4 \%$ of all infections, respectively.

It was observed that B. pfeifferi snails were hosts for diverse cercarial fauna (nine types), with an overall prevalence of infection of $14.7 \%$ (see Tables 3 and 4 and Fig. 2). Meanwhile B. truncatus snails served as hosts for eight types of cercariae (see Tables 3 and 4). M. tuberculata snails shed four types of cercariae and contributed to $34.7 \%$ of all infections. A total of 24 specimens of $B$. pfeifferi snails were found to be infected with $S$. mansoni, with the prevalence of infection not differing significantly between years and seasons (see Table 2). The odds of finding xiphidiocercariae in B. pfeifferi snails in 2005 was $0.25(p<0.001)$ of that in 2004, while the prevalence

Table 1 Total number of snails collected during monthly sampling in three irrigation canals etc

\begin{tabular}{|c|c|c|c|c|c|c|c|c|c|c|}
\hline \multirow[t]{2}{*}{ Species } & \multicolumn{2}{|l|}{ Site 1} & \multicolumn{3}{|l|}{ Site 2} & \multicolumn{3}{|l|}{ Site 3} & \multirow[b]{2}{*}{ Total } & \multirow[b]{2}{*}{ All sites } \\
\hline & 2004 & 2005 & Total & 2004 & 2005 & Total & 2004 & 2005 & & \\
\hline Biomphalaria pfeifferi & 401 (39.3) & $2(0.3)$ & $403(22.5)$ & $2029(62.5)$ & $390(44.5)$ & $2419(58.7)$ & 1625 (57.9) & $653(36.9)$ & $2278(49.8)$ & $5100(48.6)$ \\
\hline Bulinus truncatus & $146(14.3)$ & $423(54.9)$ & $569(31.8)$ & $242(7.5)$ & $10(1.1)$ & $252(6.1)$ & 309 (11.0) & $273(15.4)$ & $582(12.7)$ & $1403(13.4)$ \\
\hline Bulinus forskalii & $4(0.4)$ & $14(1.8)$ & $18(1.0)$ & $165(5.1)$ & $333(38.0)$ & $498(12.1)$ & $6(0.2)$ & $2(0.1)$ & $8(0.2)$ & $524(5.0)$ \\
\hline Lymnea natalensis & $161(15.8)$ & $93(12.1)$ & $254(14.2)$ & $67(2.1)$ & $2(0.2)$ & $69(1.7)$ & $0(0.0)$ & $6(0.3)$ & $6(0.1)$ & $329(3.1)$ \\
\hline Physa acuta & $58(5.7)$ & $116(15.0)$ & $174(9.7)$ & $432(13.3)$ & $135(15.4)$ & $567(13.8)$ & $0(0.0)$ & $0(0.0)$ & $0(0.0)$ & $741(7.1)$ \\
\hline Melanoides tuberculata & $146(14.3)$ & $39(5.1)$ & $185(10.3)$ & $306(9.4)$ & $6(0.7)$ & $312(7.6)$ & 867 (30.9) & $836(47.2)$ & $1703(37.2)$ & $2200(21.0)$ \\
\hline Cleopatra bulimoides & 105 (10.3) & $84(10.9)$ & $189(10.5)$ & $5(0.2)$ & $1(0.1)$ & $6(0.1)$ & $1(0.0)$ & $0(0.0)$ & $1(0.0)$ & $196(1.9)$ \\
\hline Total & 1021 & 771 & 1792 & 3246 & 877 & 4123 & 2808 & 1770 & 4578 & 10493 \\
\hline
\end{tabular}


Table 2 Associations between snail counts for 3 snail species or infections in these and various factors tested one by one together with site so as to adjust for variation among sites

\begin{tabular}{|c|c|c|c|c|c|c|c|}
\hline \multirow[t]{2}{*}{ Factor (coding first category base) } & \multicolumn{3}{|c|}{ Snail density (Count ratios) } & \multicolumn{4}{|c|}{ Infections in snails (Odds ratios) } \\
\hline & $\begin{array}{l}\text { Biomphalaria } \\
\text { pfeifferi }\end{array}$ & $\begin{array}{l}\text { Bulinus } \\
\text { truncatus }\end{array}$ & $\begin{array}{l}\text { Melanoides } \\
\text { tuberculata }\end{array}$ & $\begin{array}{l}\text { Schistosoma } \\
\text { mansoni } \\
\text { (B. pfeifferi) }\end{array}$ & $\begin{array}{l}\text { Xiphidio } \\
\text { cercariae } \\
\text { (B. pfeifferi) }\end{array}$ & $\begin{array}{l}\text { Xiphidio } \\
\text { cercariae } \\
\text { (B. truncatus) }\end{array}$ & $\begin{array}{l}\text { Parapleurolo-phocercous } \\
\text { cercariae (M. tuberculata) }\end{array}$ \\
\hline Year (2004 - 2005) & $0.13^{* * *}$ & 0.85 & $0.30^{* *}$ & 0.35 & $0.29^{*}$ & $1.43^{*}$ & $0.63^{* * *}$ \\
\hline Season (Summer - Winter) & 1.74 & $2.61^{*}$ & 0.55 & 0.67 & 0.75 & $1.65^{* *}$ & 0.95 \\
\hline Water temperature $\left({ }^{\circ} \mathrm{C}\right)$ & 0.92 & 0.97 & $1.09^{*}$ & 0.97 & $1.26^{* * *}$ & 0.98 & 0.98 \\
\hline Water temperature (previous month) & 0.95 & 0.99 & 1.02 & 0.96 & $1.22^{* * *}$ & $1.16^{* * *}$ & 0.99 \\
\hline Depth $(\leq 0.10 \mathrm{~m}->0.10 \mathrm{~m})$ & $0.33^{*}$ & 0.81 & $0.32^{*}$ & 0.33 & $0.32^{* * *}$ & 1.28 & 0.63 \\
\hline Flow speed $(\leq 0.40 \mathrm{~m} / \mathrm{s}->0.40 \mathrm{~m} / \mathrm{s})$ & 2.24 & 1.02 & $3.05^{*}$ & 0.85 & $0.55^{* * *}$ & $0.61^{* * *}$ & 0.68 \\
\hline Turbidity (Clear-turbid) & 1.09 & 0.49 & 1.84 & 1.52 & $0.61^{* *}$ & $0.56^{* *}$ & 1.13 \\
\hline Vegetation cover ( $\leq 40 \%$ - >40 \%) & 2.26 & 1.39 & 0.89 & 3.12 & $3.98^{* * *}$ & $1.24^{*}$ & $1.30^{*}$ \\
\hline
\end{tabular}

Numbers are exponentially transformed regression confidents from negative binomial regression on snail counts (count ratio) or from logistic regression on infection status of these snails (odds ratios)

$\left.\left.\left.{ }^{*}\right) p<0.05 ;{ }^{* *}\right) p<0.01 ;{ }^{* *}\right) p<0.001$

of infection did not differ between seasons (see Table 2). The maximum monthly overall prevalence (three sites combined) of xiphidiocercariae infection in B. pfeifferi snails was 37.4 (number of snails collected was 174). Only two specimens of $B$. truncatus snails were found to be infected with schistosomes. The odds of finding xiphidiocercariae in B. truncatus snails in 2005 was 1.51 $(p<0.001)$ of that in 2004, and the odds of infection during winter was $1.62(p<0.001)$ of that during summer months (see Table 2). The maximum monthly overall prevalence of xiphidiocercariae infection in B. truncatus snails was $74.1 \%$ (number of snails collected was 135 ). The odds of finding parapleurolophocercous cercariae in $M$. tuberculata snails did not differ significantly between years and seasons. The maximum monthly overall prevalence of parapleurolophocercous cercariae (see Fig. 2) in $M$. tuberculata snails was $47.3 \%$ (number of snails collected was 93).

The mean monthly water temperature (mean of three sites) ranged from $22.3^{\circ} \mathrm{C}$ to $28.0{ }^{\circ} \mathrm{C}$ in the summer, and from $16.0{ }^{\circ} \mathrm{C}$ to $27.7{ }^{\circ} \mathrm{C}$ in the winter. The air temperature ranged from $27.7{ }^{\circ} \mathrm{C}$ to $37.0{ }^{\circ} \mathrm{C}$ in the summer, and from $20.3{ }^{\circ} \mathrm{C}$ to $38.0{ }^{\circ} \mathrm{C}$ in the winter. Only the density of $M$. tuberculata snails was associated with water temperature (see Table 2): the odds of finding xiphidiocercariae in snails increased with higher water temperature, as well as with water temperature from the previous month. Monthly mean water depth varied significantly in both seasons, i.e. from 0.3 to $43 \mathrm{~cm}$ during the entire period. Monthly mean water velocity ranged from 0.2 to $0.9 \mathrm{~m} / \mathrm{s}$ in the summer, and from 0.6 to $1.2 \mathrm{~m} / \mathrm{s}$ in the winter. Water turbidity records varied; water was clear in April and generally turbid in October. Water depth, current speed, and turbidity are linked; generally, coverage by aquatic macrophytes ranged from $10-75 \%$ in both seasons. High coverage by aquatic vegetation was associated with higher odds of finding infected snails (see Table 2).

\section{Discussion}

This study found a generally high density of snails in the irrigation canals studied, as well as a diverse trematode fauna, with 20 morphotypes of cercariae identified, some of which might represent more than one species. The prevalence of infection in some snail species is high. The most common snail species found was B. pfeifferi and although the numbers of snails infected with $S$. mansoni are relatively few, this level of infection seems to be sufficient to maintain intense transmission to humans, as schistosomiasis is perceived as a major problem in the human host. This is in line with earlier findings [32]. In a previous study undertaken in this area (from 2003 to 2004), it was noted that although a high percentage of school children were infected with S. haematobium and $S$. mansoni, there were very few snails infected with these trematodes in the adjacent irrigation canals [26].

Although the design of these irrigation systems is similar to that of the Gezira-Managil scheme, it is noteworthy that minor canals in our study area do not support schistosome intermediate hosts, which is in contrast with the Gezira irrigated area, where minor canals constitute the most important transmission sites [13, 20].

It was observed in this study that the density of snails varied over the years. Usually in intermittent irrigation systems, snail density is greatly affected by irrigation practices and canal maintenance. Thus, the speed of the water in the abueshreens may be high during the initial period after an irrigation cycle has begun and this may dislodge snails that are then carried downstream. Canal maintenance such as vegetation or mud removal contributes to the removal of the snails and thus greatly influences the size of snail populations. Therefore, the 

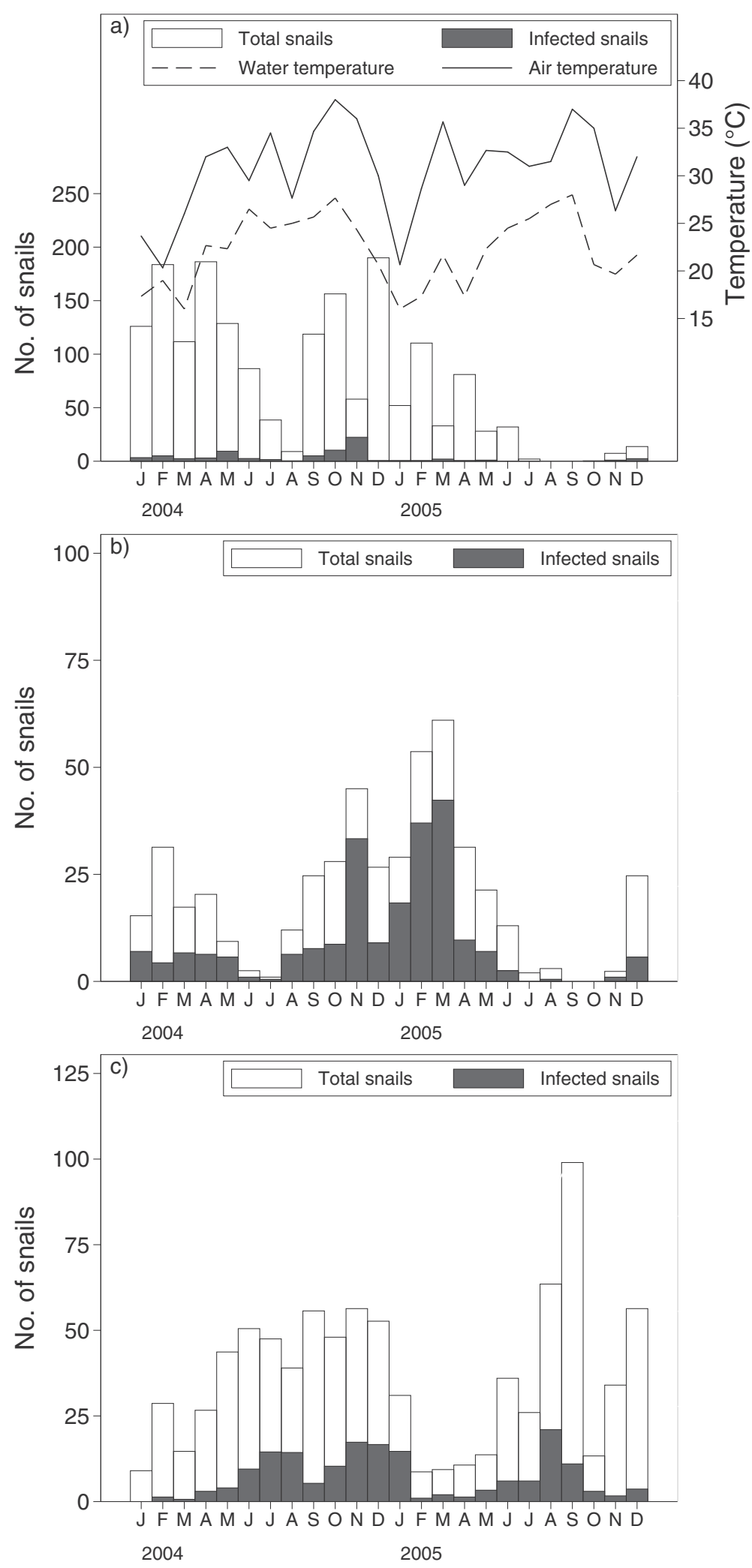

Fig. 2 Density of snails (number of snails per standard search), infected snails, and mean water and air temperature, by month, from January 2004 to December 2005, in the East Nile locality, Khartoum, Sudan. a Biomphalaria pfeifferi infected with any trematodes, (b), Bulinus truncatus infected with xiphidiocercariae, (c) and Melanoides tuberculata infected with parapleurolophocercous cercariae 
Table 3 Number of infections recorded in 5 different snail species collected from three irrigation canals

\begin{tabular}{|c|c|c|c|c|c|c|c|c|c|}
\hline \multirow[b]{2}{*}{ Cercariae type } & \multicolumn{3}{|l|}{ Site } & \multicolumn{5}{|l|}{ Snail species } & \multirow[b]{2}{*}{ Total } \\
\hline & $\overline{\text { Site } 1}$ & Site 2 & Site 3 & $\begin{array}{l}\text { Biomphalaria } \\
\text { pfeifferi }\end{array}$ & $\begin{array}{l}\text { Bulinus } \\
\text { truncatus }\end{array}$ & $\begin{array}{l}\text { Bulinus } \\
\text { forskalii }\end{array}$ & $\begin{array}{l}\text { Melanoides } \\
\text { tuberculata }\end{array}$ & $\begin{array}{l}\text { Cleopatra } \\
\text { bulimoides }\end{array}$ & \\
\hline Xiphidiocercariae (4 types) & $452(82.8)$ & $281(90.6)$ & $152(24.2)$ & $176(80.7)$ & $657(95.9)$ & 0 & $51(9.9)$ & $1(1.6)$ & $885(59.6)$ \\
\hline Parapleurolophocercous & $24(4.4)$ & $2(0.6)$ & $410(65.2)$ & 0 & 0 & 0 & $436(84.7)$ & 0 & $436(29.4)$ \\
\hline Vivax (LPM) & $60(11.0)$ & $2(0.6)$ & $1(0.2)$ & 0 & 0 & 0 & 0 & $63(98.4)$ & $63(4.2)$ \\
\hline Avian schistosome (BAD) & 0 & 0 & $26(4.1)$ & 0 & 0 & 0 & $26(5.0)$ & 0 & $26(1.8)$ \\
\hline S. mansoni & $1(0.2)$ & $14(4.5)$ & $9(1.4)$ & $24(11.0)$ & 0 & 0 & 0 & 0 & $24(1.6)$ \\
\hline Amphistome cercariae & $6(1.1)$ & $7(2.3)$ & $4(0.6)$ & 0 & $17(2.5)$ & 0 & 0 & 0 & $17(1.1)$ \\
\hline Strigea (LPD) & 0 & 0 & $8(1.3)$ & $7(3.2)$ & $1(0.1)$ & 0 & 0 & 0 & $8(0.5)$ \\
\hline Echinostome & 0 & $1(0.3)$ & $5(0.8)$ & $4(1.8)$ & $2(0.3)$ & 0 & 0 & 0 & $6(0.4)$ \\
\hline Type 5 & 0 & 0 & $4(0.6)$ & $1(0.5)$ & $3(0.4)$ & 0 & 0 & 0 & $4(0.3)$ \\
\hline Type 7 & 0 & 0 & $4(0.6)$ & $1(0.5)$ & $2(0.3)$ & $1(33.3)$ & 0 & 0 & $4(0.3)$ \\
\hline S. haematobium & $1(0.2)$ & $1(0.3)$ & 0 & 0 & $2(0.3)$ & 0 & 0 & 0 & $2(0.1)$ \\
\hline Type 1 & 0 & $2(0.6)$ & 0 & 0 & 0 & $2(66.7)$ & 0 & 0 & $2(0.1)$ \\
\hline Type 2 & 0 & 0 & $2(0.3)$ & $2(0.9)$ & 0 & 0 & 0 & 0 & $2(0.1)$ \\
\hline Type 3 & 0 & 0 & $2(0.3)$ & $2(0.9)$ & 0 & 0 & 0 & 0 & $2(0.1)$ \\
\hline Type 6 & $2(0.4)$ & 0 & 0 & 0 & 0 & 0 & $2(0.4)$ & 0 & $2(0.1)$ \\
\hline LA & 0 & 0 & $1(0.2)$ & 0 & $1(0.1)$ & 0 & 0 & 0 & $1(0.1)$ \\
\hline Type 4 & 0 & 0 & $1(0.2)$ & $1(0.5)$ & 0 & 0 & 0 & 0 & $1(0.1)$ \\
\hline Total snails infected & 546 & 310 & 629 & 218 & 685 & 3 & 515 & 64 & 885 (59.6) \\
\hline Total types & 7 & 8 & 14 & 9 & 8 & 2 & 4 & 2 & 17 \\
\hline
\end{tabular}

Table 4 Measurements of the cercariae $(\mu \mathrm{m})$

\begin{tabular}{llll}
\hline Cercarial type & Body length & Tail stem & Tail furcae \\
\hline S. mansoni & 152 & 242 & 73 \\
S. haematobium & 140 & 227 & 73 \\
Avian (BAD) & 145 & 262 & 91 \\
Amphistome & 169 & 351 & - \\
Echinostome & 413 & 737 & - \\
LA & 78 & 293 & 56 \\
Parapleurolophocercous & 223 & 1048 & - \\
Strigea (LPD) & 157 & 212 & 201 \\
Vivax (LPM) & 140 & 200 & 150 \\
Type 1 & 83 & 443 & - \\
Type 2 & 80 & 194 & 161 \\
Type 3 & 105 & 195 & 151 \\
Type 4 & 159 & 248 & 131 \\
Type 5 & 126 & 339 & 111 \\
Type 6 & 68 & 194 & 57 \\
Type 7 & 106 & 176 & 146 \\
Armatae xiphidiocercariae & 99 & 113 & - \\
Ornatae xiphidiocercariae & 96 & 106 & - \\
Type 1 xiphidiocercariae & 102 & 110 & - \\
Type 2 xiphidiocercariae & 67 & 92 & - \\
\hline
\end{tabular}

effect of other potential factors, such as seasonal temperature fluctuations and growth of aquatic macroand-micro-flora, may be difficult to assess.

Prevalence of trematode infections in snails is high in this area, and this is clearly an important factor for snail population density fluctuations and transmission of schistosomes through antagonism between trematode species or direct pathological effects of trematodes on snails. In the Gezira irrigation system, it was noted that larval echinostomes are abundant in local populations of B. truncatus snails, a factor that may to some extent be responsible for the uneven distribution and low prevalence of S. haematobium in the region [33].

Larval trematodes may act as regulators of snail populations if prevalence of infection in natural snail populations is high $[34,35]$. It is known that certain trematodes may, in some cases, be responsible for the elimination of snail populations [1]. Some of these species might be manipulated to achieve biological control of snail-transmitted diseases [36, 37]. Larval trematode infections can also be used as bio indicators of environmental quality [38, 39], in that a change in species richness and prevalence of infection over time may reflect environmental change.

Double infections in snails are rare in this area, and this has been attributed to inter-species antagonism [40, 41]. 


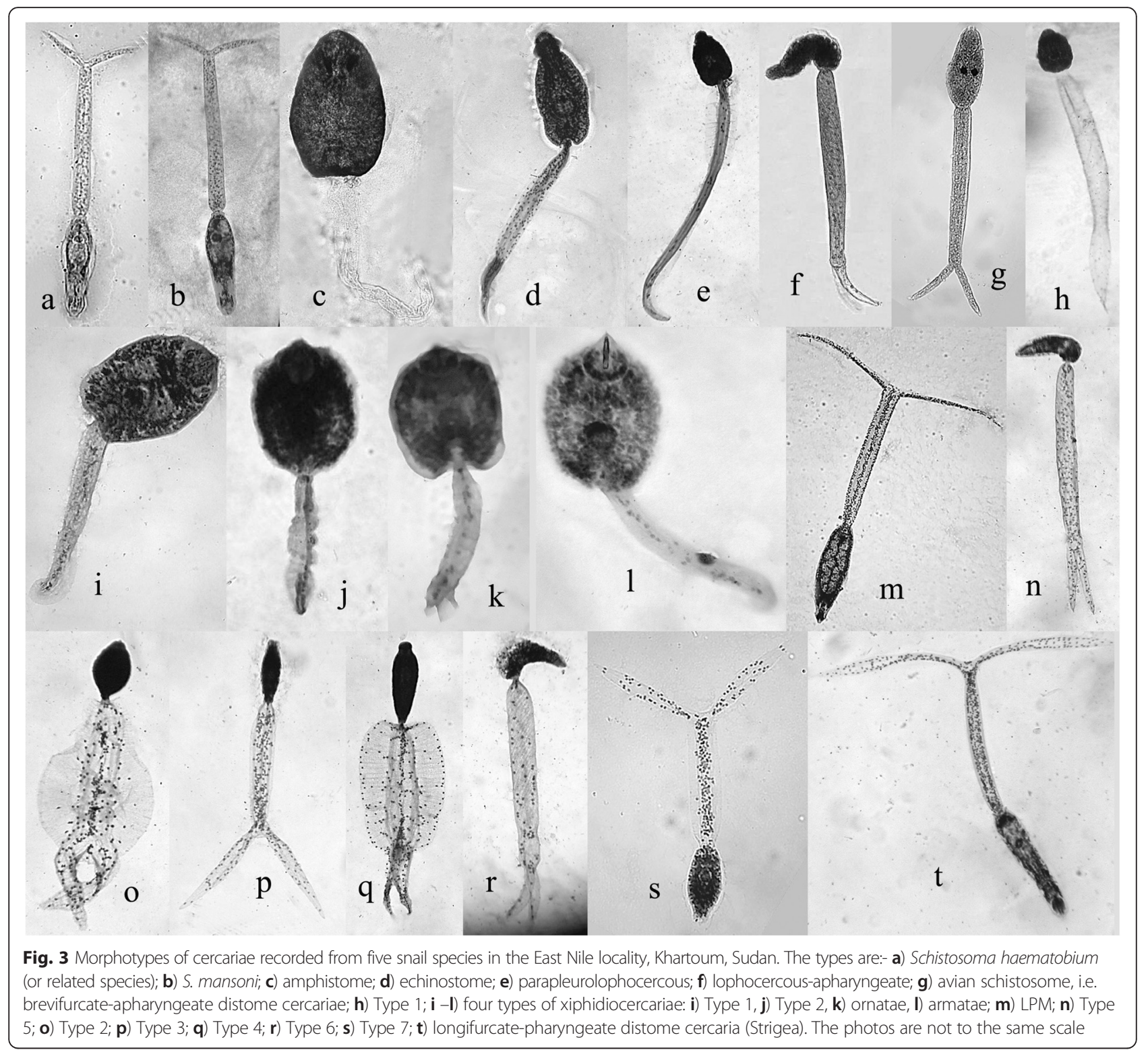

Possibly, the low prevalence of S. haematobium infections in B. truncatus snails in the present study could be due to antagonism by xiphidiocercariae, which were found with high rates. Sousa [42] also speculated that double infections could be more pathogenic when compared to single species infections. As a result, snails with multiple infections face higher chances of mortality compared to those with single infections, and may therefore be underrepresented in snail collections. However, temporal and spatial variations in the abundance of eggs and miracidia of different trematode species have been considered to be more important in determining how often a snail is simultaneously infected by two or more species or how often established infections are challenged [42-46].
Whether the diverse trematode fauna also reflect high diversity of potential final hosts, both aquatic and terrestrial species, remains to be studied. Loss of biodiversity could adversely affect human health, with multiple potential reasons for this [47-50]

No infections were found in L. natalensis and P. acuta snails in this study, however this is in contrast to other studies. For example, it was found that $L$. natalensis was the most important intermediate snail host for transmitting a wide variety of trematodes in Tanzania [1]. Many records in Egypt pointed to $P$. acuta being the most infected snail in the freshwater snail community $[51,52]$. Resistance of snails to trematode infections has been reported to play a role in determining prevalences rates of 
infection [53]. However, low numbers of snails with larval trematodes were recorded in the present study, and it has been reported that prevalence of larval trematode infections are dependent on snail numbers [54-56].

With the exception of brevifurcate apharyngeate monostome cercaria, the cercarial types reported by Chingwena et al. [57] in Zimbabwe were all recorded in the present study, in addition to new ones. Amphistome cercariae were recorded in B. tropicus, B. globosus, B. forskalii, and B. pfeifferi snails in Zimbabwe [57]. In the present study, these cercariae were recovered only from $B$. truncatus snails. Results from the present study suggest that B. pfeifferi and B. truncatus snails may be major hosts for a variety of larval trematodes, as they together harbor 15 types of trematode cercariae. However B. tropicus was the most important intermediate snail host for transmitting a wide variety of trematode species in Zimbabwe [57].

This study demonstrated that transmission of trematodes in this area and the prevalence of infection in the snail hosts are very intense. In order to explain the observed distribution patterns further studies are required to identify final hosts for most of these species and to further explore the possibility that these trematodes can be augmented so as to either affect snail populations directly or prevent transmission of trematodes of medical and/or veterinary importance.

\section{Conclusion}

Besides schistosome species, several other larval trematodes are prevalent. Especially xiphidiocercariae, were very prevalent in B. truncatus snails. Since these trematodes cause mortality among snails and possibly compete with schistosomes within intermediate hosts (antagonism), we suggest that further studies be undertaken to test whether prevalence of some of these other trematode could be augmented to an extent where they could be used in the biological control of schistosomiasis

\section{Additional file}

Additional file 1: Multilingual abstracts in the six official working languages of the United Nations. (PDF $383 \mathrm{~kb}$ )

\section{Abbreviation}

LPM: longifurcate-pharyngeate monostome cercariae Vivax.

\section{Competing interests}

The authors declare that they have no competing interests.

\section{Authors' contributions}

NAIM and AARMA participated in the study design, field and laboratory work, and manuscript preparation. HM assisted in the analysis and presentation of the results. All authors actively contributed to the analysis and interpretation of the results. All authors read and approved the final manuscript.

\section{Acknowledgements}

All laboratory activities were undertaken in the Schistosomiasis Research Laboratory, Department of Zoology, Faculty of Science, University of Khartoum. The surveys could not have been completed without the support of the Department of Zoology, which allowed the use of their car to drive to the sampling sites.

\section{Author details}

'Department of Zoology, Khartoum College of Medical Sciences, Khartoum, Sudan. ${ }^{2}$ Parasitology and Aquatic Diseases, Department of Veterinary Disease Biology, Faculty of Health and Medical Sciences, University of Copenhagen, Frederiksberg, Denmark. ${ }^{3}$ Education Expert Company, Riyadh, Kingdom of Saudi Arabia.

Received: 24 July 2015 Accepted: 15 February 2016

Published online: 25 February 2016

\section{References}

1. Loker ES, Moyo HG, Gardner SL. Trematode- gastropod associations in nine non- lacustrine habitats in Mwanza region of Tanzania. Parasitol. 1981;83:381-99.

2. Chu KY, Dawood IK, Nabi HA. Seasonal abundance of trematode cercariae in Bulinus truncatus in a small focus of schistosomiasis in the Nile Delta. Bull World Health Organ. 1972:47:420-2.

3. Ahmed AM, ElTash LA, Mohamed EY, Adam I. High levels of Schistosoma mansoni infections among school children in central Sudan one year after treatment with Praziquantel. J Helminthol. 2012;86:228-32.

4. AbdEIRahman M, AbuGedeiri YB, Ahmed AM, Magzoub M, ElSharief O, Musa S. Prevalence of intestinal schistosomiasis in New Halfa scheme, Eastern Sudan. Khart Med J. 2010:3:448-51.

5. Mahgoub HM, Mohamed AA, Magzoub M, Gasim Gl, Eldein WN, Ahmed AA, et al. Schistosoma mansoni infection as a predictor of severe anaemia in schoolchildren in eastern Sudan. J Helminthol. 2010;84:132-5.

6. Ahmed AM. Schistosomiasis in Gunaid Sugar Cane Scheme, Sudan. J Nat Scien. 2007:11:139-47.

7. Hilali AHM, Madsen H, Daffalla AA, Wassila M, Christensen NØ. Infection and transmission pattern of Schistosoma mansoni in the Managil irrigation scheme, Sudan. Ann Trop Med Parasitol. 1995;89:279-86.

8. Eltoum IA, Sulaiman SM, Elturabi HE, Mahgoub E, Homeida MM. Infection with Schistosoma mansoni in two different endemic areas: a comparative population-based study in Elzeiedab and Gezira-Managil irrigation schemes, Sudan. J Trop Med Hyg. 1993;96:100-6.

9. Hilali AHM, Gindi AMH, Babiker EM, Daffalla AA. Snails, schistosomiasis and expansion in irrigation around Khartoum State, Sudan. In: Madsen $\mathrm{H}$, Kristensen TK, Ndlovu P, editors. Proceedings of "A Workshop on the Status of Research on Medical Malacology in Relation to Schistosomiasis in Africa", Zimbabwe, August 1995. Charlottenlund, Denmark/Harare, Zimbabwe: Danish Bilharziasis Laboratory and Blair Research Laboratory; 1996. p. 165-76.

10. Ahmed AM, Osman HA, Mansour FA, Gasim Gl, Dam I. Schistosoma haematobium infections among school children in central Sudan one year after treatment with praziquantel. Parasit Vect. 2012;5:108.

11. Ahmed AA, Afifi AA, Adam I. High prevalence of Schistosoma haematobium infections in Gereida Camp in Darfur, Sudan. Ann Trop Med Parasitol. 2009;103:741-3.

12. Elias $E$, Daffalla A, Lassen JM, Madsen $H$, Christensen NØ. Schistosoma haematobium infection patterns in the Rahad Irrigation Scheme, Sudan. Acta Trop. 1994;58:115-25.

13. Babiker SM, Blankespoor HD, Wassila M. Transmission of Schistosoma haematobium in North Gezira, Sudan. J Trop Med Hyg. 1985;88:65-73.

14. Majid AA, Hussein MF, Taylor MG. Age specific prevalence and intensity of Schistosoma bovis infection in Sudanese Desert sheep in the White Nile Province. Res Vet Sci. 1983;35:120-1.

15. Majid AA, Marshall TF, Hussein MF, Bushara HO, Taylor MG, Nelson GS, et al. Observations on cattle Schistosomiasis in the Sudan, a study in comparative Medicine: I. Epizootiological observations on Schistosoma bovis in the White Nile Province. Am J Trop Med Hyg. 1980;29:435-41.

16. Haroun EM, El Sanhouri AA, Gameel AA. Response of goats to repeated infections with Fasciola gigantica. Vet Parasitol. 1989;30:287-96.

17. Yagi Al, Younis SA, Haroun EM, Gameel AA, Bushara HO, Taylor MG. Studies on heterologous resistance between Schistosoma bovis and Fasciola gigantica in Sudanese cattle. J Helminthol. 1986;60:55-9. 
18. Afifi AA, Ahmed AA. Some indigenous aquatic insects as biocontrol agents against different stages of schistosome intermediate hosts. J Facult Scien Technol. 2011;2:100-16.

19. Ahmed AA, Ahmed SA. Extracts of leaves and seeds of the Neem tree, Azadirachta indica, as environment-oriented molluscicides for combating schistosomiasis. In: Madsen $\mathrm{H}$, Appleton CC, editors. Proceedings of Workshop on African Freshwater Malacology, 9-12 September 2003. Kampala, Uganda: DBL Institute for Health Research and development; 2006. p. 235-49.

20. Madsen H, Daffalla AA, Karoum KO, Frandsen F. Distribution of freshwater snails in irrigation schemes in the Sudan. J Appl Ecol. 1988;25:853-66.

21. Karoum KOA. Trials on biological control of the intermediate hosts of Schistosomiasis in the Gezira Agricultural Scheme by competitor snail species. Ph.D. Thesis. Faculty of Veterinary Science, University of Khartoum; 1988.

22. Hilali AM, Desougi LA, Wassila M, Daffalla AA, Fenwick A. Snails and aquatic vegetation in Gezira irrigation canals. J Trop Med Hyg. 1985;88:75-81.

23. Amin MA. Large scale assessment of the molluscicides copper sulphate and $\mathrm{N}$-tritglmorpholine (Frescon) in the north group of the Gezira irrigated area, Sudan. J Trop Med Hyg. 1972;75:169-75.

24. Eltoum MA. Sudan Climate. Cairo, Egypt: Institute of Arab Research and Studies; 1974

25. Osman BA. Studies on transmission and control of schistosomiasis in irrigation schemes in Khartoum State, Sudan. Ph.D. Thesis. University of Khartoum, Faculty of Science, Department of Zoology; 2000.

26. Abdien H. T. Observations on the Transmission Pressure of Schistosomiasis and Soil Transmitted Helminthes in El Kiryab Scheme, Khartoum, State. M.Sc. thesis. University of Khartoum, Faculty of Science, Zoology Department; 2006.

27. Danish Bilharziasis Laboratory. A Field Guide to Freshwater Snails in Countries of The WHO Eastern Mediterranean Region. Danish Bilharziasis Laboratory;1983.

28. Frandsen F, Christensen N. An introductory guide to the identification of cercariae from African freshwater snails with special reference to cercariae of medical and veterinary importance. Acta Trop. 1984;41:181-202.

29. Schell SC. Hand Book of Trematodes of North America (north of Mexico) University Press of Idaho, 1985.

30. Hilbe JM. Negative Binomial Regression. Cambridge, UK.: Cambridge University Press; 2008.

31. Hilbe JM. Logistic Regression Models. Chapman \& Hall/CRC Press,2010.

32. Webbe G. Transmission of Bilharziasis.2. Production of Cercariae. Bull Wld Hlth Org. 1965:33:155-62

33. McCullough FS. Biological control of the snail intermediate hosts of human Schistosoma spp.: a review of its present status and future prospects. Acta Trop. 1981;38:5-14.

34. May RM. Parasitic infections as regulators of animal populations. Am Sci. 1983;71:36-45

35. Brown KM, Leathers BK, Minchella DJ. Trematode prevalence and population dynamics of freshwater pond snails. Amer Midl Nat. 1988;120:289-301.

36. Combes $C$. Trematodes, antagonism between species and sterilizing effects on snails in biological control. Parasitol. 1982;84:151-75.

37. Davis NE. Population dynamics of and larval trematode interactions with Lymnaea tomentosa and the potential for biological control of schistosome dermatitis in Bremner Bay, Lake Wanaka, New Zealand. J Helminthol. 1998;72:319-24.

38. Kuris AM, Lafferty KD. Community structure: larval trematodes in snail hosts. Annu Rev Ecol Syst. 1994;25:189-217.

39. Keas BE, Blankespoor HD. The prevalence of cercaria from Stagnicola emarginata (Lymnaeidae) over 50 years in North Michigan. J Parasitol. 1997;83:536-40.

40. Sousa WP. Interspecific antagonism and species coexistence in a diverse guild of larval trematode parasites. Ecol Monog. 1993;63:103-28.

41. Lafferty KD, Sammond DT, Kuris AM. Analysis of larval trematode communities. Ecol. 1994:75:2275-85.

42. Sousa WP. Interspecific interaction of larval trematode parasites of freshwater marine snails. Am Zool. 1992;32:583-92.

43. Sousa WP. Spatial scale and the processes structuring a guide of larval trematode parasites. In: Esch GW, Bush AO, Aho JM, editors. Parasite communities. Patterns and Procedures. London: Chapman and Hall; 1990. p. 41-67.
44. Toledo R, Mouňoz-Antolí C, Pérez M, Esteban J. Larval trematode infections in freshwater gastropods from Albufera Natural Park in Spain. J Helminthol. 1998;72:79-82.

45. Fernandez JC, Esch GW. Guild structure of larval trematodes in the snail Helisoma anceps : patterns and process at the individual host level. J Parasitol. 1991;77:528-39.

46. Fernandez JC, Esch GW. The component community structure of trematodes in the pulmonate snail Helisoma anceps. J Parasitol. 1991;77:540-50.

47. Sandifer PA, Sutton-Grier AE, Ward BP. Exploring connections among nature, biodiversity, ecosystem services, and human health and well-being: Opportunities to enhance health and biodiversity conservation. Ecosystem Serv. 2015;12:1-15

48. Campbell K, Cooper D, Dias B, Prieur-Richard A-H, Campbell-Lendrum D, Karesh WB, et al. Strengthening international cooperation for health and biodiversity. Eco Health. 2011:8:407-9.

49. Hough RL. Biodiversity and human health: evidence for causality? Biodivers Conserv. 2014:23:267-88.

50. Pongsiri MJ, Roman J, Ezenwa VO, Goldberg TL, Koren HS, Newbold SC, et al. Biodiversity loss affects global disease ecology. BioScience. 2009:59:945-54

51. Williams JA, Esch GW. Infra- and component community dynamics in the pulmonate snail Helisoma anceps, with special emphasis on the hemiurid trematode Halipegus occidualis. J Parasitol. 1991;77:246-53.

52. Yousif F, Ibrahim A. Four new xiphidiocercariae from freshwater prosobranchs in Egypt. J Egypt Soc Parasitol. 1979;9:411-9.

53. Badawy BE, Rizk ET, Barakat SM, Mona M. On the distribution of freshwater snails, in Kafr El- Sheikh Province, and their natural infections with larval trematodes with emphasis to snail vectors of schistosomiasis. Proc ICBS. 2000;1:613-29.

54. Bayne CJ, Yoshino TP. Determinants of compatibility in molluscs- trematode parasitism. Amer Zool. 1989;29:399-407.

55. Ewers $\mathrm{WH}$. The influence of the density of snails on the incidence of larval trematodes. Parasitol. 1964:54:579-83.

56. Anderson RM, May RM. Prevalence of schistosome infection within molluscan populations: observed and theoretical predictions. Parasitol. 1979;79:63-94

57. Chingwena G, Mukaratirwa S, Kristensen TK, Chimbari M. Larval trematode infections in freshwater snails from the highveld and lowveld areas of Zimbabwe. J Helminthol. 2002;76:283-93.

\section{Submit your next manuscript to BioMed Central and we will help you at every step:}

- We accept pre-submission inquiries

- Our selector tool helps you to find the most relevant journal

- We provide round the clock customer support

- Convenient online submission

- Thorough peer review

- Inclusion in PubMed and all major indexing services

- Maximum visibility for your research

Submit your manuscript at www.biomedcentral.com/submit 